$7 \quad{ }^{1}$ Department of Microbiology, Quaid-i-Azam University, Islamabad Pakistan.

$8 \quad{ }^{2}$ Department of Biosciences, University of Wah, Wah Cantt, Pakistan.

9

$10 *$ Corresponding author

11 Dr. Safia Ahmed

12 Professor

13 Department of Microbiology

14 Quaid-i-Azam University, Islamabad 45320

15 Pakistan.

16 E-mail: safiamrl@yahoo.com

17

18

19 These authors contributed equally to this work and RS did all the experimental work and SA

20 supervised this research work.

\author{
Rabia Saleem ${ }^{1,2}$ Safia Ahmed ${ }^{1 *}$
}

\section{Bacteria \\ Isolation and Characterization of L-Glutaminase producing}




\section{Abstract}

23 Being a significant protein L-glutaminases discovers potential applications in various divisions running from

24 nourishment industry to restorative and cure. It is generally disseminated in microbes, actinomycetes, yeast and

25 organisms. Glutaminase is the principal enzyme that changes glutamine to glutamate. The samples were gathered

26 from soil of Taxila, Wah Cantt and Quetta, Pakistan for the isolation of glutaminase producing bacteria. After

27 primary screening, subordinate screening was done which includes multiple testification such as purification,

28 observation of morphological characters and biochemical testing of bacterial strains along with 16S rRNA sequence

29 homology testing. Five bacterial strains were selected showing glutaminase positive test in screening, enzyme

30 production via fermentation and enzymatic and protein assays. Taxonomical characterization of the isolates

31 identified them as Bacillus subtilis U1, Achromobacter xylosoxidans G1, Bacillus subtilis Q2, Stenotrophomonas

32 maltophilia U3 and Alcaligenes faecalis S3. The optimization of different effectors such as incubation time,

33 inducers, carbon source, $\mathrm{pH}$, and nitrogen source were also put under consideration. There was slight difference

34 among incubation of bacterial culture, overall, 36 hours of incubation time was the best for glutaminase production

35 by all the strains. Optimal pH was around 9 in Achromobacter xylosoxidans $\mathrm{G} 1$ and Alcaligenes faecalis $\mathrm{S} 3$, pH 6 in

36 Bacillus subtilis U1, pH 8 in Stenotrophomonas maltophilia U3, pH 6-8 in Bacillus subtilis Q2. Best glutaminase

37 production was obtained at $37^{\circ} \mathrm{C}$ by Bacillus subtilis U1and Bacillus subtilis Q2, $30^{\circ} \mathrm{C}$ for Achromobacter

38 xylosoxidans G1, Stenotrophomonas maltophilia $\mathrm{U} 3$ and $25^{\circ} \mathrm{C}$ by Alcaligenes faecalis $\mathrm{S} 3$. The carbon sources put

39 fluctuated effects on activity of enzyme in such a way that glucose was the best carbon source for Bacillus subtilis

40 U1and Bacillus subtilis Q2, Sorbitol for Achromobacter xylosoxidans G1 and Alcaligenes faecalis S3 while xylose

41 was the best for Stenotrophomonas maltophilia U3. Yeast extract and Trypton were among good nitrogen sources

42 for Achromobacter xylosoxidans G1 and of Bacillus subtilis U1 respectively. Glutamine was the best inducer for

43 Bacillus subtilis Q2, Alcaligenes faecalis S3 and Stenotrophomonas maltophilia U3, while lysine for Achromobacter

$44 x y l o s o x i d a n s$ G1 and glycine act as good inducer in case of Bacillus subtilis U1. After implementation of optimal

45 conditions microbial L-glutaminase production can be achieved and the bacterial isolates have a great potential for

46 production of glutaminase enzyme and their applications.

47 Key words: L-Glutaminase, characterization, enzyme production and optimization. 


\section{8 \\ Introduction}

49 Being the most important entity in multiple biological and non-biological processes, enzymes

50 play crucial role in maintaining and sustaining industrial, commercial and economical products.

51 They include all biochemical response and accelerate the rate of response without being

52 expressing themselves in the last product [1].

53 L-Glutaminase is amidohydrolase enzyme belong to hydrolytic class which catalyzes the

54 conversion of amino acid L-glutamine into L-glutamic acid, in the presence of water and releases

55 ammonia. This enzyme plays an important role in nitrogen metabolism at cellular level. This

56 enzyme is present in both microorganisms such as bacteria fungi and yeast as well as in macro-

57 organisms, so this is ubiquitous in nature [2]. The probable sources may include animals, plants,

58 bacteria, actinomycetes, yeast and fungi [3]. Numerous bacteria are involved in synthesis of

59 extracellular and intracellular glutaminases such as Bacillus sp., Pseudomonas, Actinobacterium

60 sp, and E. coli. [4].

61 The focal sources of fungal glutaminases are Aspergillus sp. and Trichoderma sp. [6]. The

62 glutaminase producing actinomycetes includes different species [7]. Plant tissue are also used in

63 the production but the evidences of extraction of plant's glutaminases are not too much due to

64 less feasible approaches [8]. Due to complex organization, animals are not well known in the

65 field of enzymatic isolation from their tissues [10]. So, microbes are the main source of enzymes.

66 The approaches towards enzymatic production involved fermentation techniques, mainly of two

67 types i.e. solid-state fermentation (SSF) and submerged fermentation $(\mathrm{SmF})[11,12]$. 
68 Catalysts represent $80 \%$ of the complete mechanical market. Requests for chemical utilized in

69 ventures are expanding step by step so as to improve the procedures [13].

70 L-Glutaminase is considered to be the most important enzyme in food industries, for enhancing

71 the taste and aroma of fermented food $[14,15]$. L-Glutaminsae is a potential anticancer enzyme,

72 flavor enhancer, an antioxidant, and utilized as biosensor for deciding glutamine and glutamate

73 [16]. Due to importance of this enzyme the present research is carried out to isolate new bacterial

74 strains for glutaminase production.

\section{Materials and methods}

\section{Sample collection}

77 For isolation of microorganism soil samples were collected from Taxila, Wah Cantt and Quetta,

78 Pakistan, kept in aseptic conditions in the lab and stored at $-4^{\circ} \mathrm{C}$. One bacteria strain was also

79 isolated from old hydrolyzed glutamine sample.

$80 \quad$ Primary screening

\section{$81 \quad$ Isolation and screening of microorganism}

82 For the isolation of bacteria from soil samples rapid plate method technique were used. The plate

83 media were prepared whose composition was $\mathrm{NaCl} 0.5, \mathrm{KCl} 0.5, \mathrm{MgSO}_{4} 7 \mathrm{H}_{2} \mathrm{O} .0 .5, \mathrm{KH}_{2} \mathrm{PO}_{4} 1$,

$84 \mathrm{FeSO}_{4} .7 \mathrm{H}_{2} \mathrm{O} 0.1, \mathrm{ZnSO}_{4} 0.1 \mathrm{gm} / \mathrm{L}$, L-Glutamine 0.5 as Nitrogen source and phenol red $(0.002$

$85 \mathrm{~g} / \mathrm{L}$ ) for indicator of glutaminase activity by bacteria. After sterilization of media soil samples

86 were sprinkled on medium and plates were incubating at $37^{\circ} \mathrm{C}$ in a thermal incubator. Bacteria 
87 which showed change in color around the colony due to basic $\mathrm{pH}$ were considered as glutamine

88 producers and further proceeded.

\section{Production of Glutaminase by fermentation method}

90 Five bacterial isolates were selected and used for production of L-Glutaminase in fermentation

91 media. The bacterial strains were inoculated in $500 \mathrm{ml}$ Erlenmeyer flasks in screening media

92 containing g/L Glucose, 10.0; Glutamine 5.0; $\mathrm{Na}_{2} \mathrm{HPO}_{4} .2 \mathrm{H}_{2} \mathrm{O}, 6.0 ; \mathrm{KH}_{2} \mathrm{PO}_{4}, 3.0 ; \mathrm{MgSO}_{4}, 0.49$;

$93 \mathrm{CaCL}_{2}, 0.002$ and incubated in a shaking incubator for $96-120$ hours at $25-37^{\circ} \mathrm{C}$ for bacteria at

$94120 \mathrm{rpm}$. The sample was collected at regular interval of 24 hours and centrifuged at $6000 \mathrm{rpm}$

95 for $15 \mathrm{~min}$ at $4^{\circ} \mathrm{C}$. The supernatant containing enzyme was collected and stored at $4^{\circ} \mathrm{C}$.

96 Secondary screening

\section{$97 \quad$ Purification of bacterial strains}

98 Isolates of bacteria which showed best activity in rapid plate assay were chosen and further

99 purified by streak plate methods.

100 Extracellular enzyme activity by zone of hydrolysis

101 Purified bacterial strains were checked for extracellular enzyme activity by zones of hydrolysis.

102 Very few cells of bacteria were inoculated on mid of screening media plates. Change in color 103 was detected after 24 hrs. 


\section{Extracellular enzyme activity by well diffusion method}

105 Bacterial isolates cultivated on production media and cell free broth was inoculated in wells (100

$106 \mu \mathrm{l})$ in the screening media plates and next day the color change of the medium was observed and

107 zone of hydrolysis was recorded.

\section{Enzyme assay}

109 The reaction mixture of enzyme assay contains $0.5 \mathrm{ml}$ of Tris. HCL buffer of $\mathrm{pH} 8.0,0.5 \mathrm{ml}$ of

$110100 \mathrm{mM}$ L-Glutamine; a substrate of L-Glutaminase, $0.5 \mathrm{ml}$ of crude enzyme and $0.5 \mathrm{ml}$ of

111 distilled water. The reaction mixture was then incubated in a water bath at $37 \pm 2^{\circ} \mathrm{C}$ for 30 min.

112 After incubation $0.5 \mathrm{ml}$ of Trichloroacetic acid (TCA) was added for termination of reaction. In

$113 \quad 3.7 \mathrm{ml}$ of distilled water in a separate test tube $0.1 \mathrm{ml}$ of reaction mixture was added and finally

$1140.2 \mathrm{ml}$ of Nessler reagent was added for estimation of nitrogen present in a sample [17]. The

115 absorbance was measured at $450 \mathrm{~nm}$ and compared with standard curve to calculate Unit of 116 enzyme.

\section{Protein Estimation}

118 Presence of extracellular protein in the crude enzyme was estimated by lowery method [18].

119 Bovine serum albumin (BSA) was used as a standard.

\section{Bacterial Identification}

121 For identification of bacterial strains gram staining, morphological characters and biochemical 122 tests were performed.

\section{Gram staining}


124 The reagents used in gram staining was crystal violet, gram iodine, ethanol and safranin. The

125 reaction time for all of these reagents were 1 min except ethanol which is kept for 5 seconds on

126 the slide. The color of the strains was observed along with other features under the microscope.

\section{Morphological characterization}

128 The bacterial strains were morphologically characterized on nutrient agar plates. The strains

129 were streaked and incubated overnight and colony morphology was assessed in terms of size,

130 pigmentation, shape, margin, elevation and opacity.

\section{Biochemical test}

132 Different biochemical tests were performed for identification taxonomy of bacterial strains.

133 These biochemical tests include indole production, urease, catalase, oxidase, starch hydrolysis,

134 carbohydrates fermentation (glucose, sucrose, lactose, xylose, mannose, and maltose), mannitol

135 salt agar, and citrate utilization test using standard protocol [19].

\section{Molecular characterization}

\section{DNA isolation}

138 For the extraction of DNA, a modified phenol chloroform DNA extraction method was

139 performed. DNA was re-suspended in $30 \mu \mathrm{l}$ of TE buffer in the tube and mixed the DNA pallet

140 through pipetting and stored at $4^{\circ} \mathrm{C}$. Isolated DNA was checked by gel electrophoresis using 0.8

$141 \%$ agarose. The DNA purity was observed by using spectrophotometer with an absorbance in a

142 ratio of $\mathrm{A}_{260 / 280}$. 


\section{Amplification of 16S rRNA gene}

144 Genomic DNA extracted from different bacteria was amplified by using PCR (Labnet

145 international, Model: MultiGene OptiMax, USA). Reaction cycles were optimized by checking

146 the PCR cycle times, melting and annealing temperature using universal primer 27F and $1492 \mathrm{R}$.

147 The PCR reaction was carried out in a final volume of $25 \mu 1$ containing $2.5 \mu 11 \mathrm{x}$ PCR buffer, $5 \mu \mathrm{l}$

148 of dNTPs, $3 \mu \mathrm{l}$ of $1 \mathrm{mM} \mathrm{MgSO}_{2}, 0.75 \mu \mathrm{l}$ (IU) Taq DNA Polymerase, $1 \mu \mathrm{l}$ of $10 \mu \mathrm{M}$ Forward

149 primer, $1 \mu \mathrm{l}$ of $10 \mu \mathrm{M}$ Reverse Primer, $2 \mu \mathrm{l}$ of bacterial Template DNA and $10.75 \mu 1$ double

150 distilled $\mathrm{H}_{2}$ O. Amplification of DNA was carried out in 30 cycles for 1 hour and 40 minutes.

151 For which each cycle run $1^{\text {st }} 10$ second at $98^{\circ} \mathrm{C}$ then next 45 seconds at $94^{\circ} \mathrm{C}, 50$ seconds at $52^{\circ} \mathrm{C}$

152 and then cycle was run at $72^{\circ} \mathrm{C}$ for 1 minutes and finished with 10 minutes at $72^{\circ} \mathrm{C}$ for final

153 extension. The PCR amplified products were confirmed with the help of agarose gel

154 electrophoresis.

\section{Sequencing of $16 \mathrm{~S}$ rRNA gene}

156 The sequencing $16 \mathrm{~S}$ rDNA amplified products of all the samples of bacteria conducted

157 commercially. The sequences were blast with the help of BLASTN on the site of National Center

158 for Biotechnology Information (NCBI). The sequences were used to make phylogenetic tree of

159 all the bacterial strains was made by the aid of maximum likelihood method which cleared about

160 evolutionary basis of strains. 


\section{Optimization of culture conditions for L-Glutaminase production}

162 Optimization of multiple conditions leading to production of glutaminase was done by estimating

163 optimal conditions such as effect of incubation time, $\mathrm{pH}$, carbon source, nitrogen source and

164 inducers.

165 Effect of incubation time

166 Glutaminase production by bacterial isolates was done at $30^{\circ} \mathrm{C}$ in fermentation media and

167 activity was measured after specific intervals (0, 1, 2, 3, 4 and 5 days).

168 Effect of $p H$

169 The condition of $\mathrm{pH}$ was optimized for the production of glutaminase by the selected bacterial

170 isolate by running fermentation at different $\mathrm{pH}(6-9)$.

171 Effect of Temperature

172 Selected bacterial strains were optimized for the effect of temperature at $25^{\circ} \mathrm{C}, 30^{\circ} \mathrm{C}$ and $37^{\circ} \mathrm{C}$.

173 Effect of carbon source

174 All the strains were checked for their enzyme producing ability at different carbon source

175 addition such as glucose, sucrose, lactose, maltose, xylose and sorbitol (1\%) in the production

176 media.

177 Effect of nitrogen source 
178 The effect of $0.1 \%$ nitrogen source was measured. The potent nitrogen sources tested were

179 Trypton, Yeast extract, Ammonium chloride and Sodium nitrate.

180 Effect of inducers

181 The glutaminase producing strains were checked for measurement of effects of different inducers

182 like Glycine, Glutamine and Lysine on glutaminase production and glutaminase activity was

183 measured after every 24 hrs of incubation.

\section{Results}

185 The present study showed the isolation and characterization of bacterial isolates with the 186 capability of producing L-glutaminase enzyme.

\section{Primary Screening}

188 The primary screening is basically the rapid plate assay technique which utilize phenol red as $\mathrm{pH}$

189 indicator. Soil samples were inoculated in the media and colonies displaying pink color

190 formation around the colonies were picked and purified and further again tested for enzyme

191 production on individual strains. Twenty bacterial colonies gave positive result in purified form

192 changing the color of media from yellow to pink (Fig 1). Five isolated Q2, U3, U1, S3 and G1

193 were selected for further analysis. After the plate rapid assay, the strains were also tested in 194 liquid media exhibiting same results.

\section{Fig 1. Primary Screening of bacteria in glutamine salt medium.}




\section{Secondary screening}

196 The secondary screening was done in media by point inoculation of bacterial strain in agar media

197 and glutaminase production was indicated as color change in agar plates. The zone of hydrolysis

198 was measured in millimeter, where glutaminase enzyme hydrolyze the substrate glutamine in a

199 medium. The results showed that all the bacterial strain produce glutaminase giving zone of

200 hydrolysis of 14-32 mm (Fig 2, Table 1). Further all the selected bacterial isolates were grown in

201 liquid media (Fig 3) and cell free broth was added in the well for measuring activity of

202 glutaminase in terms of dimeter of zone of hydrolysis in screening media. The results indicated

203 that maximum diameter of zone of hydrolysis formed by strain Stenotrophomonas maltophilia

204 U3 33 mm, Achromobacter xylosoxidans G1 was 26 mm, Bacillus subtilis U1 was 14 mm,

205 Alcaligenes faecalis S3 was $12 \mathrm{~mm}$ and Bacillus subtilis Q2 was $20 \mathrm{~mm}$. While the activity of

206 extracellular enzyme from other strains were less. The maximum zone of hydrolysis formed by

207 Bacillus subtilis U1 was $34 \mathrm{~mm}$ in its diameter while strain Alcaligenes faecalis S3,

208 Achromobacter xylosoxidans G1, Stenotrophomonas maltophilia U3 and Bacillus subtilis Q2

209 showed zone of hydrolyses of 30, 30, 23 and 16mm respectively (Fig 4, Table 1). 
Table 1 Screening of bacterial isolates for glutaminase production by Zone of hydrolysis

\begin{tabular}{|c|c|c|}
\hline Bacterial isolates & $\begin{array}{l}\text { Zone of hydrolysis (mm) } \\
\text { Secondary screening }\end{array}$ & $\begin{array}{l}\text { Extracellular activity } \\
\text { (zone of hydrolysis in mm) }\end{array}$ \\
\hline G1 & 26 & 30 \\
\hline Q2 & 20 & 30 \\
\hline S3 & 32 & 34 \\
\hline U1 & 14 & 23 \\
\hline U3 & 33 & \\
\hline
\end{tabular}

Fig 2. Zone of hydrolysis measured for L-glutaminase production by the bacterial isolates in screening media containing glutamine indicated as pink color.

Fig 3. Extracellular enzyme screening on Glutamine Salt broth

Fig 4. Extracellular enzyme activity by bacterial isolates in screening media using cell free broth in wells.

\section{Taxonomic characterization of bacterial isolates}

\section{Cultural characteristics of bacterial isolates}

224 The features like size, shape, margins, elevations, consistency, opacity and pigmentations

225 showed slight differences in all the strains. Strain S3 showed small, G1 and U3 were of medium 
226 and U1 was having large sized colonies. As the shape of colonies is concerned, colonies of G1

227 strains were rhizoid in shape while circular shape exhibited by S3 and Q2 strains and U1 and U3

228 showed filamentous shape. All the strains were having dome shaped colonies except U1 which

229 exhibited flat elevation. Colonies of all the strains were opaque and moist and showed no

230 pigmentation (Table 2).

\section{Microscopic characters of the isolates}

232 The microscopic observations such as shape, size and arrangement of cells was of different

233 phases and features and the gram staining of strains revealed that all the strains were gram

234 negative except U1 strains. The shape of the strain G1 was cocci while all others were rods

235 (Table 3).

Table 2 Cultural characteristics of Bacterial isolates.

\begin{tabular}{|l|l|l|l|l|l|l|l|}
\hline \multirow{2}{*}{\begin{tabular}{l} 
G \\
\cline { 3 - 8 }
\end{tabular}} & Size & Shape & Margins & Elevations & Consistency & Opacity & Pigmentation \\
\cline { 2 - 8 } & Medium & Rhizoids & Lobated & Dome & Moist & Opaque & Nil \\
\hline Q3 & Small & Circular & Entire & Dome & Moist & Opaque & Nil \\
\hline U1 & Large & Circular & Entire & Dome & Moist & Opaque & Nil \\
\hline
\end{tabular}




\begin{tabular}{|l|l|l|l|l|l|l|l|}
\hline U3 & Medium & Filamentous & Filiform & Dome & Moist & Opaque & Nil \\
\hline
\end{tabular}

Table 3 Microscopic characters of bacterial isolates and Gram staining.

\begin{tabular}{|l|l|l|l|l|}
\hline \multirow{2}{*}{ Strains } & \multicolumn{4}{|c|}{ Microscopic characters } \\
\cline { 2 - 5 } & Shape & Size & Arrangement & Gram reaction \\
\hline G1 & Cocci & Small & Single & Negative \\
\hline S3 & Rod & Medium & Single & Negative \\
\hline Q2 & Rod & Rod & Single & Negative \\
\hline U1 & Rod & Rod & Single & Positive \\
\hline U3 & Rod & Rod & Single & Negative \\
\hline
\end{tabular}

241 Biochemical testing

242 The biochemical tests were random except that of the strain U3 which was negative for all of the

243 test and oxidase was positive for all of the test except U3. Strains G1, S3 and G2 were catalase

244 positive and citrate utilization positive while Mannitol salt agar test was positive for G1, G2 and

245 U1. Indole production was positive for G1 and Q2 and glucose fermentation was positive for S3,

246 G2 and U1 while only strain G1 and S3 were urease positive (Table 4).

Table 4 Biochemical testing of bacterial isolates

\begin{tabular}{|c|c|c|c|c|c|c|c|}
\hline \multirow{2}{*}{$\begin{array}{c}\text { Bacterial } \\
\text { Isolates }\end{array}$} & \multicolumn{7}{|c|}{ Biochemical tests } \\
\hline & Oxidase & Catalase & Mannitol & Citrate & Indole & Glucose & Urease \\
\hline
\end{tabular}




\begin{tabular}{|c|c|c|c|c|c|c|c|}
\hline & & & $\begin{array}{l}\text { Salt agar } \\
\text { test }\end{array}$ & & Production & fermentation & \\
\hline G1 & + & + & + & + & + & - & + \\
\hline S3 & + & + & - & + & - & + & + \\
\hline Q2 & + & + & + & + & + & + & - \\
\hline U1 & + & - & + & - & - & + & - \\
\hline $\mathbf{U} 3$ & - & - & - & - & - & - & - \\
\hline
\end{tabular}

\section{Molecular characterization}

250 The agarose gel electrophoresis showed amplified sequences of 16S rRNA gene in bacterial

251 isolates. The amplified product was of 1500 bp (Figure 5). The sequences were blast in NCBI

252 database and on the basis of the homology to the sequences (> 90\%) with other bacterial strains

253 in the database the bacterial isolates were identified as Bacillus subtilis U1, Achromobacter

254 xylosoxidans G1, Bacillus subtilis Q2, Stenotrophomonas maltophilia U3 (Table 5).

Fig 5. Gel electroporation of $16 \mathrm{~S}$ rDNA amplified sequence. 
Table 5 16S rDNA sequence homology and identification

\begin{tabular}{|c|c|c|c|c|c|}
\hline Strains & $\begin{array}{l}\text { Size } \\
\text { (bp) }\end{array}$ & Sequence homology with & $\begin{array}{l}\text { Percentage } \\
\text { homology }\end{array}$ & $\begin{array}{c}\text { Accession } \\
\text { number }\end{array}$ & Identified as \\
\hline U1 & 1467 & $\begin{array}{l}\text { Bacillus subtilis strain B92 } \\
\text { 16S ribosomal RNA gene, } \\
\text { partial sequence. }\end{array}$ & $98.32 \%$ & KT719942.1 & $\begin{array}{l}\text { Bacillus subtilis } \\
\text { U1 }\end{array}$ \\
\hline $\mathrm{S} 3$ & 1369 & $\begin{array}{l}\text { Alcaligenes faecalis strain } \\
\text { SDU20 } 16 S \text { ribosomal RNA } \\
\text { gene, partial sequence }\end{array}$ & $97.87 \%$ & MN229469.1 & $\begin{array}{l}\text { Alcaligenes } \\
\text { faecalis S3 }\end{array}$ \\
\hline G1 & 805 & $\begin{array}{l}\text { Achromobacter xylosoxidans } \\
\text { strain BPS6 16S ribosomal } \\
\text { RNA gene, partial sequence }\end{array}$ & $92.35 \%$ & MK786696.1 & $\begin{array}{l}\text { Achromobacter } \\
\text { xylosoxidans G1 }\end{array}$ \\
\hline Q2 & 1200 & $\begin{array}{l}\text { Bacillus subtilis strain B18 } \\
16 \mathrm{~S} \text { ribosomal RNA gene, } \\
\text { partial sequence. }\end{array}$ & $97.87 \%$ & MK229037.1 & $\begin{array}{l}\text { Bacillus subtilis } \\
\text { Q2 }\end{array}$ \\
\hline $\mathrm{U} 3$ & 1404 & $\begin{array}{l}\text { Stenotrophomonas } \\
\text { maltophilia strain NA156 } \\
\text { 16S ribosomal RNA gene } \\
\text { partial sequence. }\end{array}$ & $96.56 \%$ & KT005287.1 & $\begin{array}{l}\text { Stenotrophomonas } \\
\text { maltophilia U3 }\end{array}$ \\
\hline
\end{tabular}




\section{Phylogenetic analysis}

259 The evolutionary history was inferred by using the Maximum Likelihood method based on the

260 Tamura-Nei model. The percentage of trees in which the associated taxa clustered together is

261 shown next to the branches. Initial tree(s) for the heuristic search were obtained automatically by

262 applying Neighbor-Join and BioNJ algorithms to a matrix of pairwise distances estimated using

263 the Maximum Composite Likelihood (MCL) approach, and then selecting the topology with

264 superior log likelihood value. The tree is drawn to scale, with branch lengths measured in the

265 number of substitutions per site. The analysis involved 25 nucleotide sequences. Codon positions

266 included were $1 \mathrm{st}+2 \mathrm{nd}+3 \mathrm{rd}+$ Noncoding. There were a total of 1012 positions in the final dataset.

267 Evolutionary analyses were conducted in MEGA X (Kumar et al., 2018, Fig 6).

Fig 6. Phylogenetic tree for the bacterial isolates showing relatedness with other organisms.

269 Microbial production of L-Glutaminase

270 Glutaminase production was done from all the bacterial isolates on Glutamine salt media and 271 optimized for various production parameters.

272 Optimization of parameters for glutaminase production

273 The optimization of glutaminase production by selected strain against different effectors like

274 incubation time, effect of $\mathrm{pH}$, effect of temperature carbon source, nitrogen source and inducers

275 were carried out in shake flask experiments. 


\section{Effect of incubation time}

277 Glutaminase production was done from all the bacterial isolates on glutamine salt media at $30^{\circ} \mathrm{C}$.

278 Fig 7 illustrating amount of enzyme being produced from strains, which showed that

279 Achromobacter xylosoxidans G1 produced highest amount of enzyme $(44.13 \mathrm{IU} / \mathrm{ml} / \mathrm{min})$ at

280 second day. At second day of incubation Bacillus subtilis Q2 was 37.30 IU/ml/min,

281 Stenotrophomonas maltophilia U3 yield 41.92 IU/ml/min, Bacillus subtilis U1 35.3 IU/ml/min

282 and Alcaligenes faecalis S3 exhibited high yield $39.71756399 \mathrm{IU} / \mathrm{ml} / \mathrm{min}$ at $4^{\text {th }}$ day of incubation.

283 At third and fourth day G1 and S3 produced high amount respectively.

Fig 7. Production of glutaminases by different bacterial isolates in glutamine salt media incubated for 4 days.

286 Results showed that Glutaminase production by Achromobacter xylosoxidans G1, Alcaligenes

287 faecalis $\mathrm{S} 3$ on production media at $37^{\circ} \mathrm{C}$ showed that optimum $\mathrm{pH}$ is 9. The strains Bacillus

288 subtilis U1, showed maximum activity at $\mathrm{pH}$ 6, Stenotrophomonas maltophilia $\mathrm{U} 3$ shown best

289 activity at $\mathrm{pH} 8$ while Bacillus subtilis Q2 also showed glutamine activity between the $\mathrm{pH}$ range

290 of 6-8 maximally (Fig 8). Achromobacter xylosoxidans G1 worked best giving activity of 57.369

$291 \mathrm{U} / \mathrm{ml} / \mathrm{min}$ at $\mathrm{pH} 9$ at $3^{\text {rd }}$ day of incubation, the activity $29.126 \mathrm{U} / \mathrm{ml} / \mathrm{min}$ of Bacillus subtilis Q2

292 was highest at $\mathrm{pH} 6$ and 8 on $2^{\text {nd }}$ day, U3 showed maximum activity at $\mathrm{pH} 8$ at third day that was

$29346.34 \mathrm{U} / \mathrm{ml} / \mathrm{min}$, Bacillus subtilis U1 showed highest activity of $37.069 \mathrm{U} / \mathrm{ml} / \mathrm{min}$ at pH 6 while

$294 \mathrm{~S} 3$ showed highest activity of $57.36 \mathrm{U} / \mathrm{ml} / \mathrm{min}$ at $\mathrm{pH} 9$. 
Fig 8. Effect of pH on glutaminase production by bacterial isolates; (a) Achromobacter

xylosoxidans G1, (b) Alcaligenes faecalis S3, (c) Bacillus subtilis U1, (d) Stenotrophomonas

maltophilia U3, (e) Bacillus subtilis Q2 on Glutamine Salt media.

\section{Effect of Temperature}

296 Glutaminase production was observed at $25^{\circ} \mathrm{C}, 30^{\circ} \mathrm{C}$ and $37^{\circ} \mathrm{C}$ by all 5 selected bacterial strains.

297 Highest Glutaminsae activity was shown at $37^{\circ} \mathrm{C}$ by Bacillus subtilis $\mathrm{U} 1$ achieved at $4^{\text {th }}$ day with

$29866.19 \mathrm{IU} / \mathrm{ml} / \mathrm{min}$ and Bacillus subtilis Q2 $(57.3 \mathrm{IU} / \mathrm{ml} / \mathrm{min})$ at $4^{\text {th }}$ day. The other strains

299 Achromobacter xylosoxidans G1 and Stenotrophomonas maltophilia U3 showed maximum

300 Glutaminase activity at $30^{\circ} \mathrm{C}$ at $3^{\text {rd }}$ day $(44.1 \mathrm{IU} / \mathrm{ml} / \mathrm{min}$ and $41.9 \mathrm{IU} / \mathrm{ml} / \mathrm{min}$ respectively). While

301 Alcaligenes Faecalis S3 best activity $\left(39.71 \mathrm{IU} / \mathrm{ml} / \mathrm{min}\right.$ ) was observed at $25^{\circ} \mathrm{C}$ at $3^{\text {rd }}$ day of

302 incubation (Fig 9).

Fig 9. Effect of Temperature on Glutaminase production by bacterial isolates on

Glutamine salt media. (a) Bacillus subtilis U1, (b) Bacillus subtilis Q2, (c) Alcaligenes

faecalis S3, (d) Achromobacter xylosoxidans G1, (e) Stenotrophomonas maltophilia U3 on

Glutamine Salt media.

303 Effect of Carbon source

304 Enzyme from strain Bacillus subtilis U1 with carbon source showed high activity on 3rd and 4th

305 day of incubation among which glucose was on highest influencing point of activity and sucrose

306 was lowest activator. The strain Stenotrophomonas maltophilia U3 got highest activity with

307 xylose as carbon source and showed least activity with glucose showing contrast feature with

308 U1. The maximum activity achieved by Bacillus subtilis Q2 which showed a universal behavior

Fig 10. Effect of Carbon source $(200 \mathrm{mM} 5 \mathrm{ml} / 50 \mathrm{ml})$ on Glutaminase production by bacterial isolates in fermentation media at $37^{\circ} \mathrm{C}$; a strain (a) Achromobacter xylosoxidans G1, (b) Alcaligenes faecalis S3, (c) Bacillus subtilis U1, (d) Stenotrophomonas maltophilia U3, (e) Bacillus subtilis Q2 on Glutamine salt media. 
309 regarding enzyme release under different carbon sources except Maltose. The highest in this case

310 was also glucose. The best activators of enzyme were glucose (Bacillus subtilis U1 \& Bacillus

311 subtilis Q2), sorbitol (Alcaligenes faecalis S3 \& Achromobacter xylosoxidans G1) and xylose

312 (Stenotrophomonas maltophilia U3) showing activities of 50.8, 60.9, 42.674, 29 and 47.66

$313 \mathrm{IU} / \mathrm{ml} / \mathrm{min}$ respectively (Fig 10).

\section{Effect of Nitrogen source}

315 The production of L-glutaminase by strain Achromobacter xylosoxidans G1 was at its higher 316 peak when yeast extract was used as nitrogen source showing $22.947 \mathrm{IU} / \mathrm{ml} / \mathrm{min}$ activity (Figure

317 11). The poorest nitrogen source was sodium nitrate and ammonium sulphate at day 1 and day 2 318 respectively. In the case of Bacillus subtilis U1 the Trypton was the best nitrogen donor showed 319 maximum activity up to $61.7828 \mathrm{U} / \mathrm{ml} / \mathrm{min}$ (Fig 11).

Fig 11. Effect of Nitrogen source $(200 \mathrm{mM} 4 \mathrm{ml} / 50 \mathrm{ml})$ for Glutaminase production by G1 (a) Archomobacter xylosoxidans G1, (b) Bacillus subtilis U1 on Mineral salt Media.

\section{Effect of Inducers}

321 The effect of inducers on all the strains were observed for 4 days. The peak achieved at $3^{\text {rd }}$ day

322 with strain U1 (Fig 12). 
Fig 12. Effect of Inducers on Glutaminase production by bacterial isolates in (a) Achromobacter xylosoxidans G1, (b) Alcaligenes faecalis S3, (c) Bacillus subtilis Q2, (d) Bacillus subtilis U1, (e) Stenotrophomonas maltophilia U3 on Glutamine salt media

323 The inducers such as Glycine, Glutamine and Lysine influenced the glutaminase activity in a 324 strain G1. The interesting feature was that all the inducer showed parabolic effect on enzyme's 325 activity such that increasing at starting point and showed highest activity at 3rd to 5th day and 326 ultimately decreased at 6th day. The glutamine tends to effect greatly on all of strain like its 327 activities in U3, S3 and Q2 were $41.92,37.069$ and $38.6 \mathrm{U} / \mathrm{ml} / \mathrm{min}$ at day $2^{\text {nd }}, 4^{\text {th }}$ and $3^{\text {rd }}$ day 328 except G1 where lysine enhanced the activity by $46.33 \mathrm{IU} / \mathrm{ml} / \mathrm{min}$ of enzyme and Bacillus 329 subtilis $\mathrm{U} 1$ showed maximum activity with glycine (41.48 IU/ml/min) (Fig 12).

\section{Discussion}

331 Since, the disclosure of L-glutaminase for its properties like anti cancerous, different microbial 332 sources is the focal point of enthusiasm for the isolation of the protein. L-glutaminase action is 333 studied in living organisms, plant tissues and microorganisms including microscopic organisms, 334 and actinomycetes. Microbial L-glutaminase (L-glutamine amido hydrolase EC 3.5.1.2) has 335 gotten more prominent consideration for its potential biotechnological applications and 336 effectiveness in wide range.

337 In the present study we have isolated 4 bacterial strains Bacillus subtilis U1, Stenotrophomonas 338 maltophilia U3, Bacillus subtilis Q2 from different soil samples and Achromobater xylosoxidane 339 G1 that was isolated from the old L-Glutamine sample. In general, glutaminases from E. coli, 
340 Bacillus spp [20] Pseudomonas spp., Citrobacter, staphylococcus [21] have been isolated and

341 well-studied.

342 The primary screening was performed on Glutamine salt media total 20 strains were isolated

343 initially out of which we have selected five isolates giving good activities in screening assays

344 giving pink color in the medium containing phenol red as indicator. Investigations of Aly [22]

345 indicated the amidase presence and activity in many organisms. Emelda [23] isolated bacteria

346 from Soil and aquatic environment screened on minimal glutamine media with phenol red as an

347 indicator and selected the colonies produced pink color due to release of ammonia into the 348 media.

349 In the bacterial screening with substrate all of the selected strains showed positive results

350 Bacillus subtilis U1 showed largest zone $34 \mathrm{~mm}$ while Bacillus subtilis Q2 gave smallest zone of

$351(16 \mathrm{~mm})$ in screening media while testing the zone of hydrolysis with cell free supernatants of

352 the isolates. This was trailed by the isolation of glutaminases from different microbial sources for

353 restorative applications $[24,25]$.

354 Taxonomic characterization of all the selected isolates were performed and all the biochemical

355 tests were positive except glucose fermentation in G1, MSA and indole tests in Alcaligenes

356 faecalis S3 and Urease in Bacillus subtilis Q2, catalase, citrate urease and indole in Bacillus

357 subtilis U1. The strain Stenotrophomonas maltophilia U3 was negative for all of biochemical

358 tests. L-Glutaminase was isolated from Bacillus subtilis which gave 50\% tests positive when 34

359 biochemical tests were performed [25].

360 The sequencing of L-Glutamisae producing strains of U1 showed $98.32 \%$ homology with

361 Bacillus subtilis strain B92, S3 has shown $97.87 \%$ homology with Alcaligenes faecalis strain 
362 SDU20, G1 was $92.35 \%$ homologous to Achromobacter xylosoxidans strain BPS6, Q2 was

$36397.87 \%$ was homologous to Bacillus subtilis strain B18 and U3 was $96.56 \%$ was homologous to

364 the Stenotrophomonas maltophilia strain NA156 on the basis of 16S ribosomal RNA gene partial

365 sequence. Molecular identification of $16 \mathrm{~S}$ rDNA analysis of L-glutaminase producing bacteria

366 identified as Bacillus subtilis JK-79 [26]. Alcaligenes faecalis KLU102 was isolated from marine

367 for glutaminase production [27]. Stenotrophomonas maltophilia and Achromobacter specie have

368 been reported for L-glutamiase production [28] [29].

369 Selected bacterial strains were optimized for incubation time, $\mathrm{pH}$, temperature, carbon source,

370 nitrogen source and effects of inducers. For incubation time Achromobacter xylosoxidans G1,

371 Bacillus subtilis Q2, Stenotrophomonas maltophilia U3 and Bacillus subtilis U1 produced

372 highest glutaminase at second day while Alcaligenes faecalis S3 showed highest activity 39.7

$373 \mathrm{IU} / \mathrm{ml} / \mathrm{min}$ at $4^{\text {th }}$ day of incubation. Maximum L-glutaminase production was achieved in

374 submerged fermentation after 18 hours of incubation time by marine isolated Bacillus subtilis

375 [30] and 72 hours of incubation for Pseudomonase VJ-6 [31].

376 The L-Glutaminase activity by Achromobacter xylosoxidans G1, Bacillus subtilis Q2,

377 Stenotrophomonas maltophilia U3, Bacillus subtilis U1 and Alcaligenes faecalis S3 was noted to

378 be best at $\mathrm{pH} 9,6,8,6,9$ with respectively. Best L-glutaminase production was observed

379 between pH 7 from the forest soil isolated bacterial strain of Bacillus sp [32]. Marine isolated

380 Vibrio azureus JK-79 shown maximum glutaminase production at $\mathrm{pH} 8$ [33].

381 Bacterial strains were optimized for glutaminase production at $25^{\circ} \mathrm{C}, 30^{\circ} \mathrm{C}$ and $37^{\circ} \mathrm{C}$.

382 Glutaminsae activity was maximum at $37^{\circ} \mathrm{C}$ by Bacillus subtilis $\mathrm{U} 1(66.19 \mathrm{IU} / \mathrm{ml} / \mathrm{min})$ and

383 Bacillus subtilis (Q2) $57.3 \mathrm{IU} / \mathrm{ml} / \mathrm{min}$ and other strains Achromobacter xylosoxidans (G1) and 
384 Stenotrophomonas maltophilia (U3) showed best activities at $30 C^{\circ}$ (Figure 9). While for

385 Alcaligenes Faecalis (S3) $25^{\circ} \mathrm{C}$ was the optimum temperature for production. Kiruthika [33]

386 isolated Vibrio azureus $\mathrm{JK}-79$ from marine, shown maximum glutaminase activity at $37^{\circ} \mathrm{C}$. $\mathrm{Al}-$

387 Zahrani [34] found $35^{\circ} \mathrm{C}$ is the best temperature for glutaminase production by Psuedomonas

388 NS16.

389 Glucose for Bacillus subtilis U1 and Bacillus subtilis Q2, sorbitol for Alcaligenes faecalis S3 and

390 Achromobacter xylosoxidans G1, xylose for Stenotrophomonas maltophilia U3 were the best

391 carbon source for glutaminase production when different carbon sources were tested (Figure 10).

392 The present study focuses on the selective isolation of the potent L-glutaminase producing soil

393 bacteria. Glucose was best carbon source for glutaminase production by Pseudomonase

394 aurignosa [34].

395 The best nitrogen source was yeast extract G1 and Trypton for U1. Maximum glutaminase

396 activity by Pseudomonas aurignosa was achieved with glutamine out of various nitrogen sources

397 [34]. Kiruthika [35] identified glutaminase production by marine Bacillus subtilis JK-79 was

398 enhanced by yeast extract.

399 The best inducer for Bacillus subtilis U1 was glycine while glutaminase production by

400 Stenotrophomonas maltophilia U3 was equally induced by glycine and glutamine, Alcaligenes

401 faecalis S3 and Bacillus subtilis Q2 showed best activities with glutamine while for

402 Achromobacter xylosoxidans G1 it was lysine. Glutaminase production was induced by

403 glutamine in case of Bacillus subtilis JK-79 and Bacillus sp. [35] [36]. 


\section{Conclusion}

405 Microbial L-glutaminases with improved properties like universal presence, thermo-resistance

406 and salt resilience discovers applications in nourishment industry just as in malignant growth

407 treatment. Utilization of atomic instruments like site coordinated mutagenesis, coordinated

408 advancement for the improvement of L-glutaminase is still at outset and further engaged research

409 is required toward this path. Wide extension still exists on the screening and choice of wild and

410 novel glutaminase creating life forms from different environmental specialties for the generation

411 of L-glutaminase and their further improvement with the assistance of present-day advances

412 [37]. Glutamine is an incredibly adaptable supplement that adds to numerous parts of mediator

413 digestion in malignant growth cells. It is especially significant in the development of the

414 macromolecules required for cell multiplication and protection from oxidative pressure. Since

415 glutamine digestion is modified during dangerous change, imaging techniques that target

416 glutamine should give a helpful window into tumor science that would supplement.

417 There is need of combination or elaboration of such system or pathways which turn away or

418 make malignant growth cell dead as well as purpose recovery impact for typical body cells and

419 improve conventional execution or working of standard cell by advancing their immunology at 420 sub-atomic level [38]. 


\section{References}

422

423

424

425

426

427

428

429

430

431

432

433

434

435

436

1. Abdallah NA, Amer SK., Habeeb MK. Screening of L-glutaminase produced by actinomycetes isolated from different soils in Egypt. Int J ChemTech R. 2012;4(4): 1451-1460.

2. Ardawi MSM, Newsholme EA. Glutamine metabolism in lymphocytes of the rat. Biochem J. 1983;212(3):835-842.

3. Binod P, Sindhu R, Madhavan A, Abraham A, Mathew AK., Beevi US, et al. Recent developments in l-glutaminase production and applications-An overview. Bioresour Technol. 2017;(245):1766-1774.

4. Amobonye A, Singh S, Pillai S. Recent advances in microbial glutaminase production and applications_-a concise review. Crit Rev Biotechnol. 2019;39(7):944-963.

5. Zhou J, Zhou J, Yang H, Yan C, Huang F. Characterization of a sodium-regulated glutaminase from cyanobacterium Synechocystis sp. PCC 6803. Sci China Ser C Life Sci. 2008;51(12):1066-1075.

6. Singh P, Banik RM. Biochemical characterization and antitumor study of Lglutaminase from Bacillus cereus MTCC 1305. Appl Biochem Biotech. 2013;171(2):522-531.

7. Teja DD, Sri Devi V, Harsha H, Vishala SS, Lakshmi KS. Production of L-glutaminase from marine ecosystems and optimal conditions for maximal production by actinomycetes. Inte J Adv Res. 2014;2(1):485-491

8. Yang YZ, Shuo Ding, Wang Y, Li C-L, Shen Y, Meeley R et al. Small kernel2 Encodes a Glutaminase in Vitamin B6 Biosynthesis Essential for Maize Seed Development. Plant Physiol. 2017;174(2):1127-1138.

9. Desai SS, Chopra S J, Hungund, B S. Production, purification and characterization of L-Glutaminase from Streptomyces sp. isolated from soil. J Appl Pharm Sci. 2016; 6(07):100-105.

10. Yano T, Ito M, Tomita K., Kumagai H. Purification and properties of glutaminase from Aspergillus oryzae. J Ferment Technol. 1988; 66(2):137-143. 
11. Sabu A, Keerthi TR, Kumar K.S, Chandrasekaran ML. Glutaminase production by marine Beauveria sp under solid state fermentation. Process Biochem. 2000; 35(7):705710.

12. Orabi H, El-Fakharany E, Abdelkhalek E, Sidke, N. Production, optimization, purification, characterization, and anti-cancer application of extracellular Lglutaminase produced from the marine bacterial isolate. Prep Biochem Biotechnol. 2020; 50(4):408-418.

13. Dube M, Schafer C, Neidhart S, Carle C. Texturisation and modification of vegetable proteins for food applications using microbial transglutaminase. Eur Food Res Tecnol. 2007; 225(2):287-299.

14. Vo TD, Sulaiman C, Tafazoli S, Lynch B, Roberts A, Chikamatsu G. Safety assessment of glutaminase from Aspergillus niger. Food Sci Nutr. 2020; 8:1433-1450.

15. Viniegra-Gonzalez G, Favela-Torres E, Aguilar CN, de Jesus Rómero-Gomez S, DiazGodinez G, Augur C. Advantages of fungal enzyme production in solid state over liquid fermentation systems. Biochem Eng J. 2003;13(2-3):157-167.

16. Awad HM, El-Deen AMN, El-Sayed E M, Hassabo AA. Biochemical studies and biological activities on L-glutaminase from rhizosphere soil Streptomyces rochei SAH2_CWMSG. Egypt Pharm J. 2019;18(1):27-41.

17. Imada A, Igarasi S, Nakahama K and Isono M: Asparaginase and glutaminase activities of microorganism. J G Microbiol. 1973; 76: 85-99.

18. Lowry OH, Rosebrough NJ, Farr AL, Randall RJ. Protein measurement with the Folin phenol reagent. J Biol Chem. 1951;193:265-275.

19. MacFaddin JF. Biochemical Tests for Identification of Medical. Bacteria. 3rd ed. Baltimore (MD): Williams and Wilkins; 2000. Analysis of Glutaminase from Different Species of Escherichia and Bacillus. Iran J Med Sci. 2016; 41(5):406-414. Species. Int J Curr Microbiol Appl Sci. 2016;(5):218-225. 
22. Aly MM, Kadi RH, Alkhatib MH, Wali AN. Production of the antitumor l-glutaminase enzyme from thermotolerant Streptomyces sp. D214, under submerged fermentation conditions. J Exp Biol Agric Sci. 2017;5(6):878-885.

23. Emelda, J. Isolation and Screening of L-asparaginase and L-glutaminase Producing Bacteria and their Antimicrobial Potential from Environmental Sources. J Phrm Biol Sci. 2016;11(3):47-53.

24. Katikala PK., Bobbarala V, Tadimalla P, Guntuku GS. Screening of L-glutaminase producing marine bacterial cultures for extracellular production of L-glutaminase. Int J Chem Tech Res. 2009;1(4):1232-1235.

25. Dubey R, Paul A, Prity N. Isolation, production and screening of anticancer enzyme LGlutaminase From Bacillus Subtilis. Int J Pharm Biol Sci. 2015;(5) 96-105.

26. Kiruthika J, Murugesan S. Studies on optimization of L-glutaminase production under submerged fermentation from marine Bacillus subtilis JK-79. Afr J Microbiol Res. 2020;14(1):16-24.

27. Pandian, SRK, Deepak V Sivasubramaniam S, Nellaiah H, Sundar K. Optimization and purification of anticancer enzyme L-glutaminase from Alcaligenes faecalis KLU102. Biologia. 2014;69(12):1644-1651.

28. Wakayama M, Yamagata T, Kamemura A. Characterization of salt-tolerant glutaminase from Stenotrophomonas maltophilia NYW-81 and its application in Japanese soy sauce fermentation. J Ind Microbiol Biotechnol. 2005; 32:383-390.

29. Blazek R, Benbough JE. Improvement in the persistence of microbial asparaginase and glutaminase in the circulation of the rat by chemical modifications. Biochim Biophys Acta. 1981;677(2):220-224.

30. Zhang X, Xu Z, Liu S, Qian K, Xu M, Yang T, Xu J, Rao Z. Improving the Production of Salt-Tolerant Glutaminase by Integrating Multiple Copies of Mglu into the Protease and 16S rDNA Genes of Bacillus subtilis 168. Molecules. 2019 Feb 7;24(3):592.

31. Jyothi H, Shivaveerakumar, Vandana R. Production of L-Glutaminase by Pseudomonas VJ-6. Res. J. Biotech. 2011;6(3):42-49.

32. Nagaraju K, Raghu Ram M. Studies on optimization of 1-glutaminase from Bacillus endophyticus RN-7. Int J Pharm Biol Sci. 2018;8(3):1146-1153. 
33. Kiruthika JS. Selective isolation and molecular identification of L-glutaminase producing bacteria from marine sediments. R J Biotech. 2013; 8(8):64-69.

34. Al-Zahrani N, Al-Qahtani S, Al-Sehri W. Microbial genetics studies on L-glutaminase producer Psuedomonas NS16 isolated from eye contact lenses. J Am Sci. 2020;16(6):34-39.

35. Kiruthika J, Nachimuthu S. Isolation and characterization of a novel L-glutaminase producing marine Bacillus subtilis strain JK-79. Asian J Microbiol Biotechnol Environ Sci. 2014;16(3):601-610.

36. Sinha S, Nigam VK. Production and characterization of 1-glutaminase by Bacillus sp. 1620. Int J Pharm Sci. 2016; 7(4):1620-1626.

37. Suzuki S, Tanaka T, Poyurovsky MV, Nagano H, Mayama T, Ohkubo S. et al. Phosphate-activated glutaminase (GLS2), a p53-inducible regulator of glutamine metabolism and reactive oxygen species. Proc Natl Acad Sci U S A. 2010;107(16):7461-7466.

38. Athira R, Elizebeth T, Narendra T, Sheik T, Gupta S, Chaudary M, Siddalingeshwara stutzeri strain under solid state fermentation using various agro residues. J Drug Deliv Ther. 2014;4(2):81-85. 



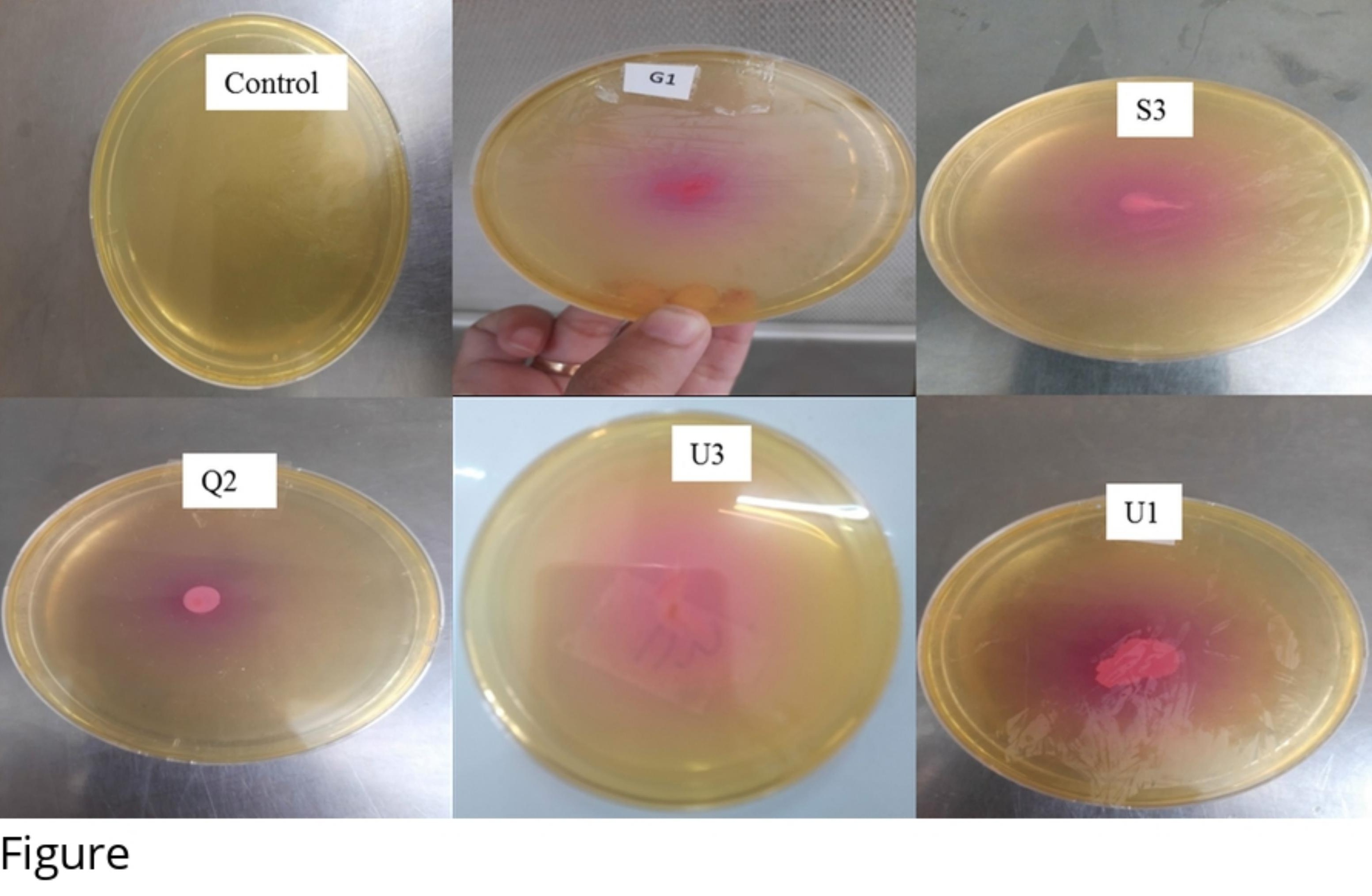

Figure 

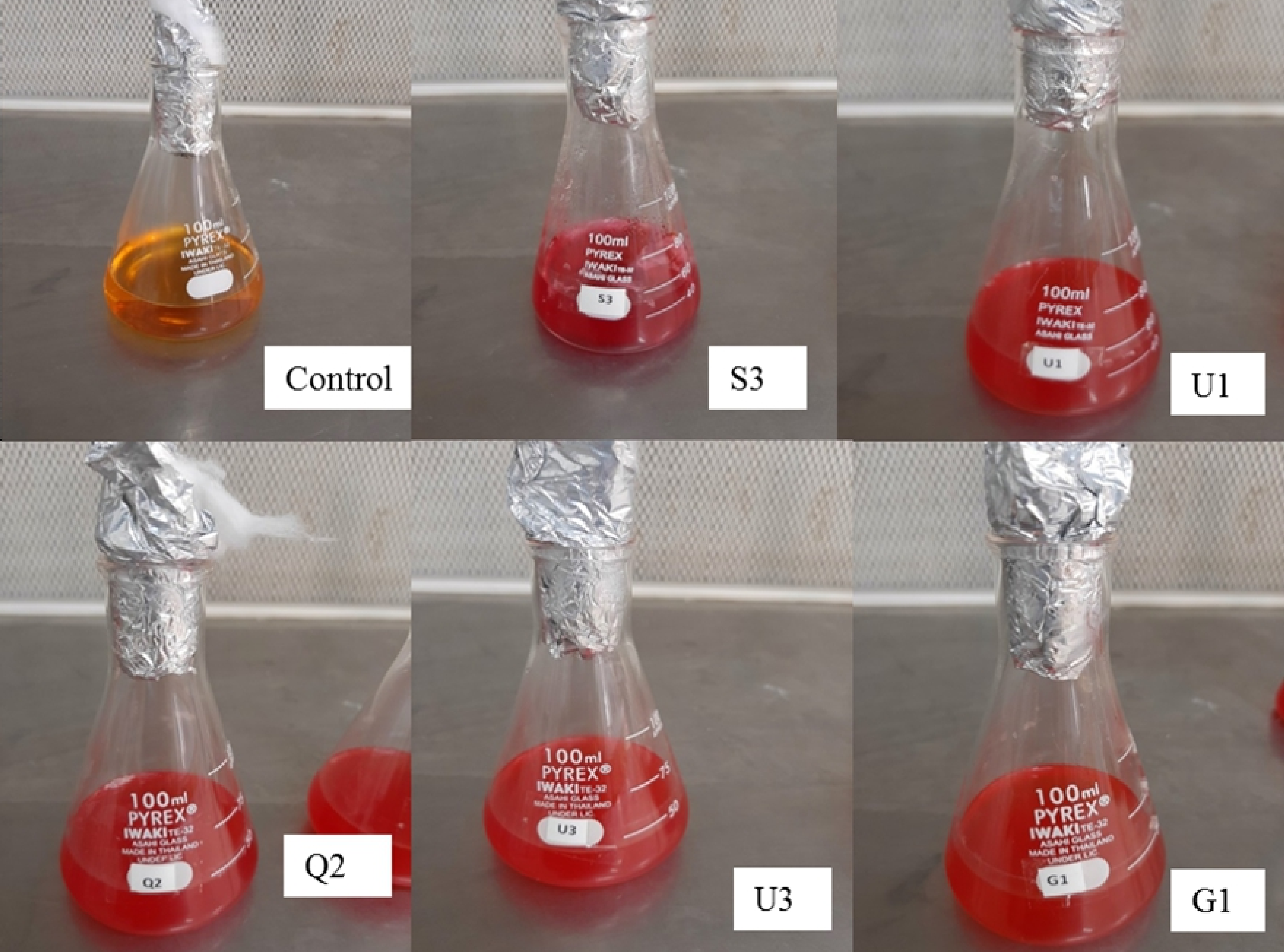

\section{Figure}




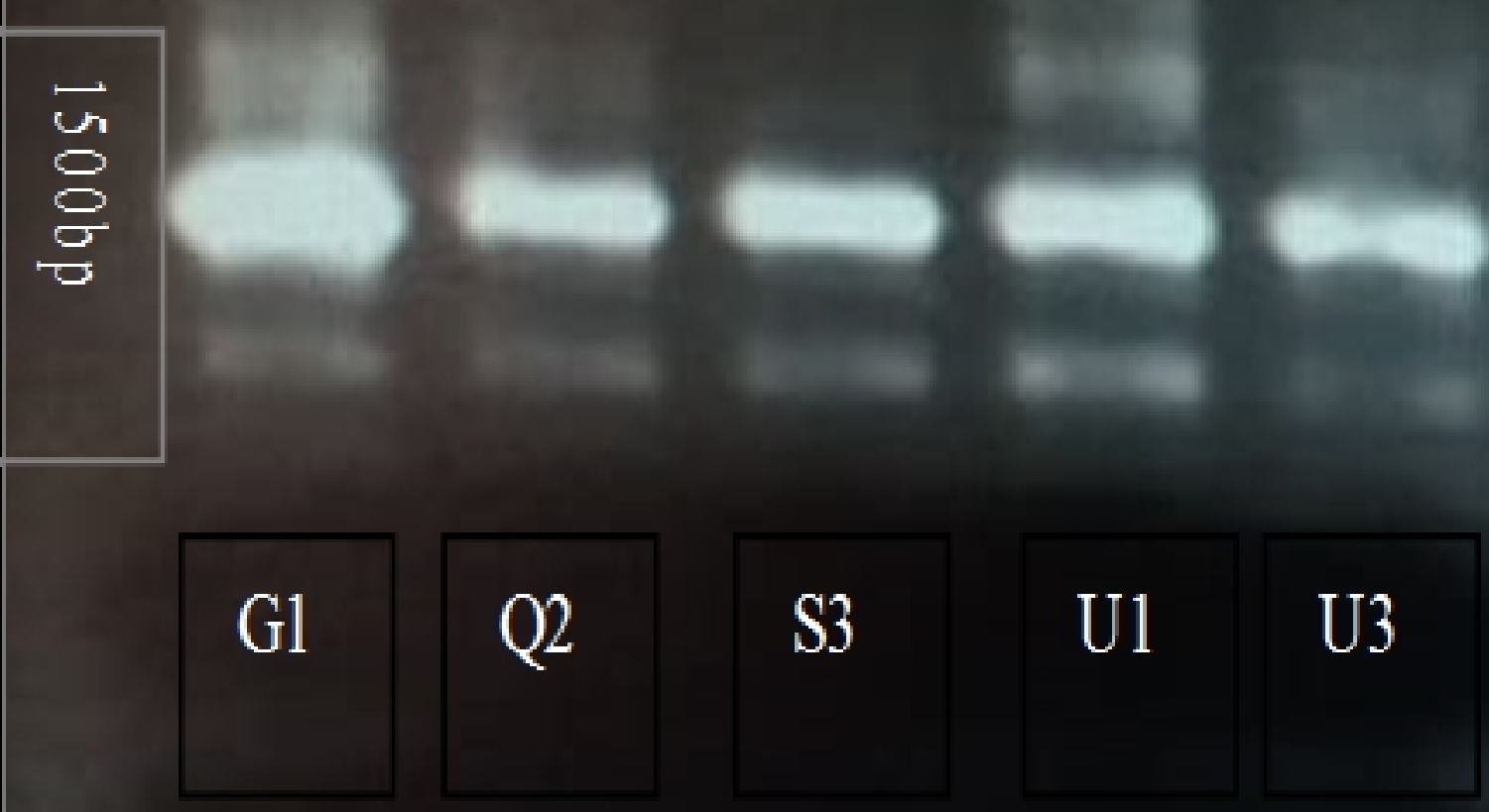




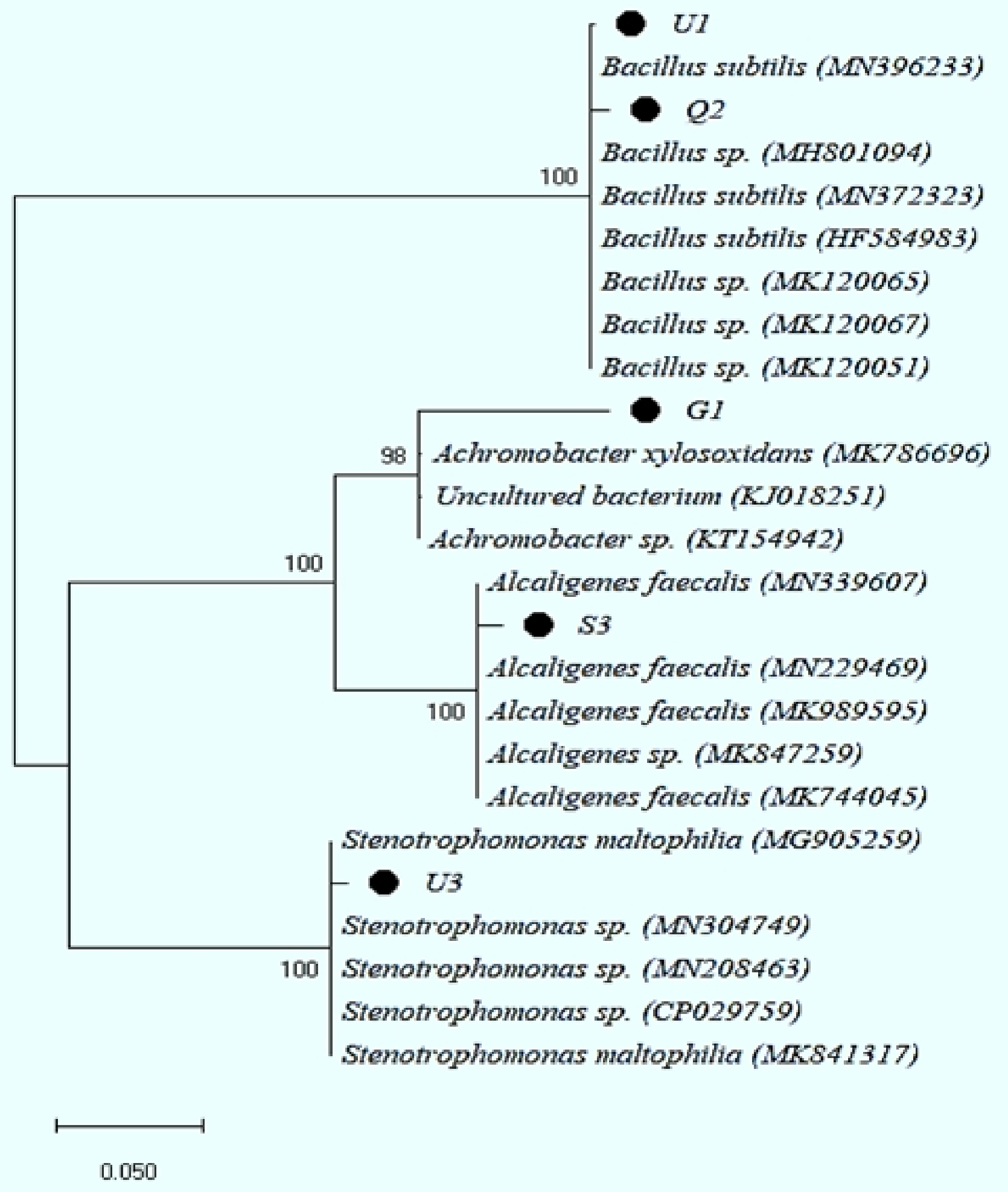




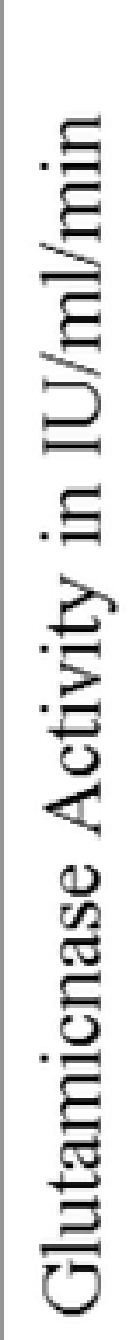

50

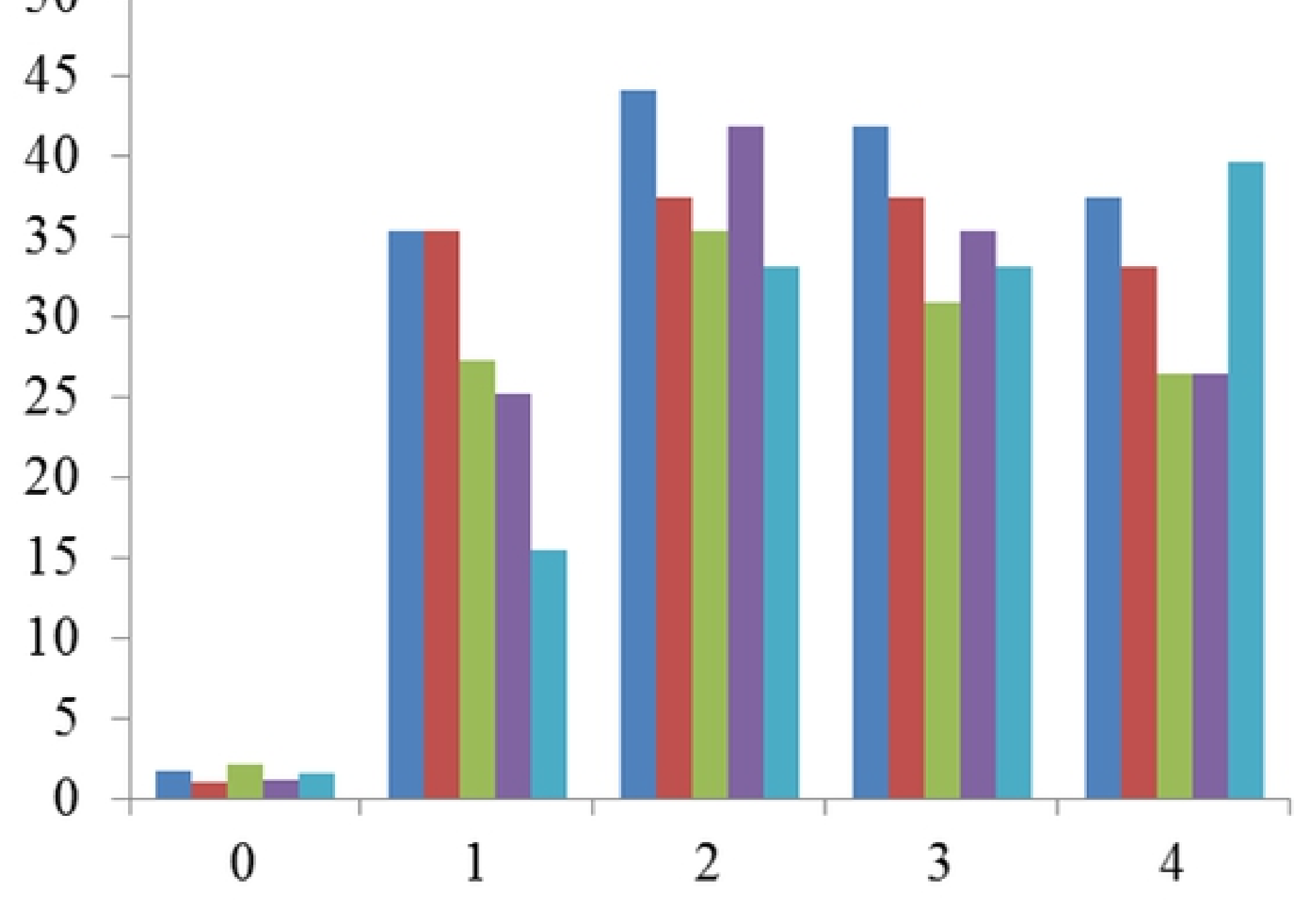

Time in days
- Achromobacter xylosoxidans (G1)

- Bacillus subtilis (Q2)

- Bacillus Subtilis(U1)

- Stenotrophomonas maltophilia (U3)

- Alcaligenes Faecal is (S3)

\section{Figure}




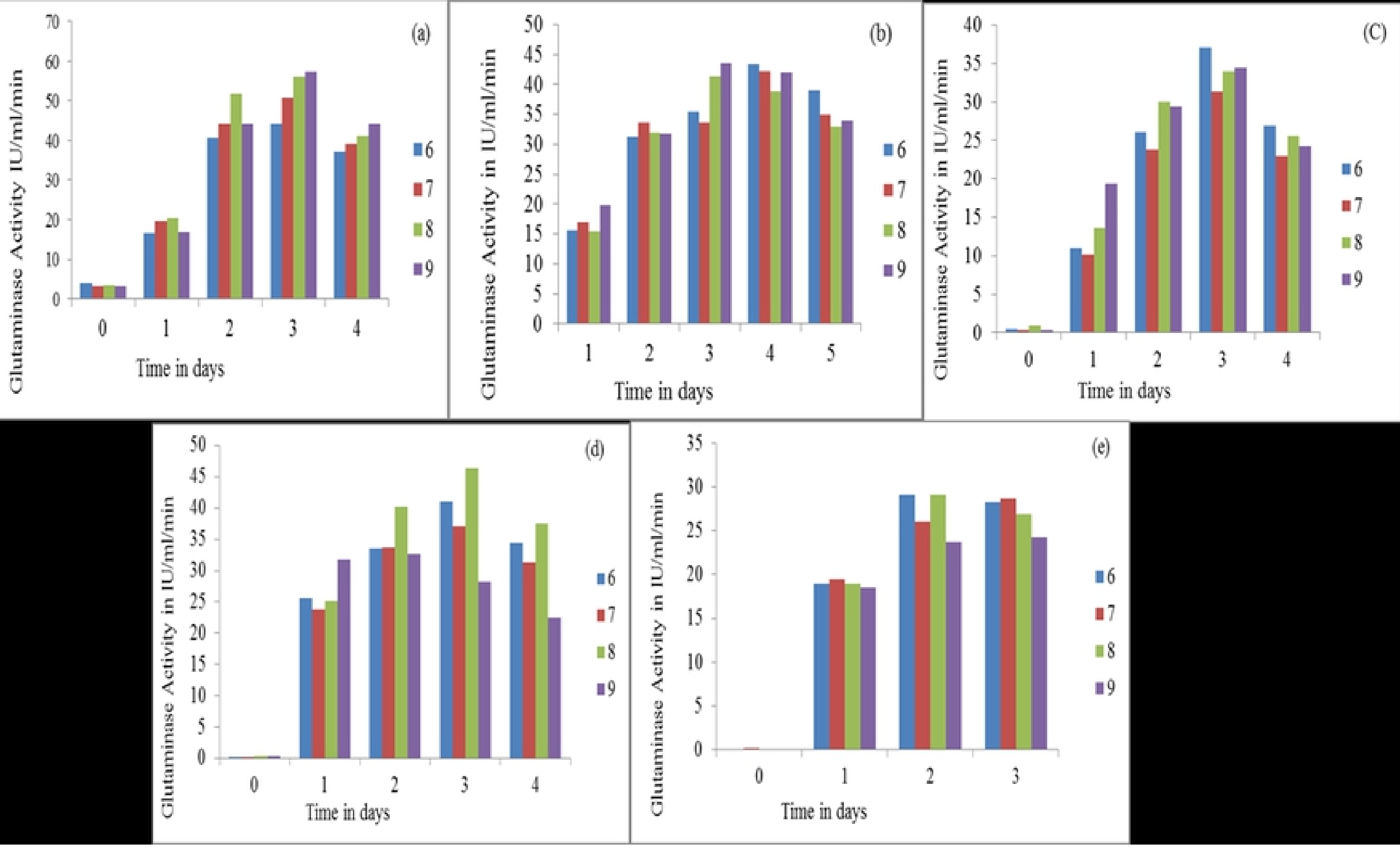

Figure 


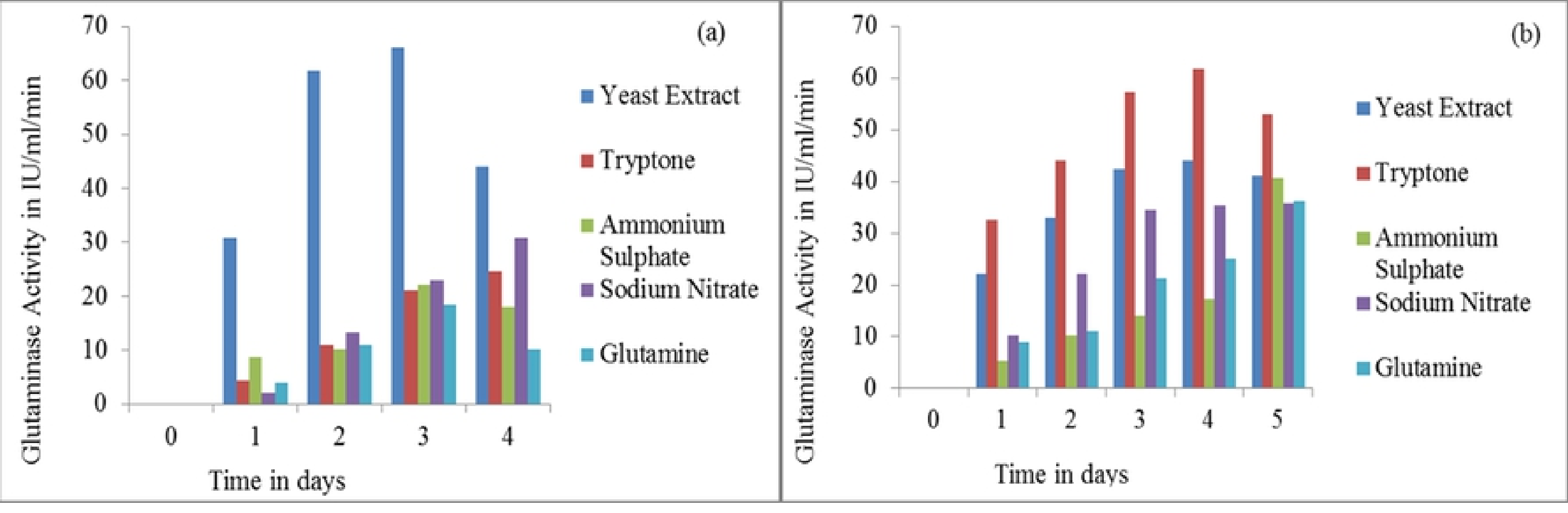

Figure 
